\title{
Patent Analysis as a New Scholarly Research Method
}

\author{
P. S. Aithal ${ }^{1} \&$ Shubhrajyotsna Aithal ${ }^{2}$ \\ ${ }^{1}$ Srinivas Institute of Management Studies, Srinivas University, Mangalore -575001, India \\ ${ }^{2}$ College of Engineering \& Technology, Srinivas University, Mangalore - 574146, India \\ E-mail: psaithal@gmail.com
}

Type of the Paper: Research Policy.

Type of Review: Peer Reviewed.

Indexed In: OpenAIRE.

DOI: http://dx.doi.org/10.5281/Zenodo1404184.

Google Scholar Citation: $\underline{\text { IJCSBE}}$

How to Cite this Paper:

Aithal, P. S. \& Aithal, Shubrajyotsna. (2018). Patent Analysis as a New Scholarly Research Method. International Journal of Case Studies in Business, IT and Education (IJCSBE), 2(2), 33- 47. DOI: http://dx.doi.org/10.5281/Zenodo.1404184.

International Journal of Case Studies in Business, IT and Education (IJCSBE)

A Refereed International Journal of Srinivas University, India.

(C) With Authors.

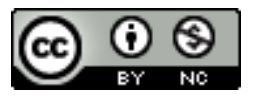

This work is licensed under a Creative Commons Attribution-Non Commercial 4.0 International License subject to proper citation to the publication source of the work.

Disclaimer: The scholarly papers as reviewed and published by the Srinivas Publications (S.P.), India are the views and opinions of their respective authors and are not the views or opinions of the S.P. The S.P. disclaims of any harm or loss caused due to the published content to any party. 


\title{
Patent Analysis as a New Scholarly Research Method
}

\author{
P. S. Aithal ${ }^{1}$ \& Shubhrajyotsna Aithal $^{2}$ \\ ${ }^{1}$ Srinivas Institute of Management Studies, Srinivas University, Mangalore -575001, India \\ ${ }^{2}$ College of Engineering \& Technology, Srinivas University, Mangalore - 574146, India \\ E-mail: psaithal@gmail.com
}

\begin{abstract}
As time progress, changes in human perception, thinking, and performance are inevitable and the same is true in research methods. There are many research methods accepted and adopted under qualitative and quantitative research umbrella and many new research methods are added by many researchers at different point of time. Such new systematic research methods provide or open a new avenue to succeeding researchers and provide an expanded opportunity to see things differently. The process ofresearch always focuses on either development of new knowledge or analysing and interpreting the existing things in a newer way. In this paper, we are proposing and forwarding a new qualitative research method called 'Patent Analysis'. This method focuses on analysis, description, and interpretation of a chosen patent in any area in a systematic way. Such analysis process of the patent might lead to the development of new concepts or theory. The procedure of patent analysis contains an evaluation of the patent in terms of its advantages, benefits, constraints, disadvantages, effectiveness, and future value. Further, the use and applications of patent analysis in the organizational strategic decisions on foreseeing the new technologies are also discussed.
\end{abstract}

Keywords: Research methods, Qualitative research, Patent analysis, Future value of patent.

\section{INTRODUCTION :}

Research is a process of investigating answers to a question in a scientific and systematic manner by means of the formulation of the hypothesis, data collection on relevant constructs, analysis and interpreting the results in a new way and reaching to the conclusions as a generalized solution. The main objectives of the research are to get familiarity with a phenomenon, find out the association or independence of an activity and identify the characteristics of an individual or a group of activities, their relationships and the frequency of occurrence. Depending on the objectives of the research, the research can be classified into exploratory research, conclusive research, descriptive research, and casual research [1].

Table 1 : Types of Research

\begin{tabular}{|l|l|l|l|}
\hline S. No. & Research Type & Objective /Purpose & Procedure \\
\hline 1 & Exploratory research & Explain the reasons for the phenomenon & Qualitative methods \\
\hline 2 & Conclusive research & $\begin{array}{l}\text { To provide information for the } \\
\text { assessment of alternative solutions }\end{array}$ & $\begin{array}{l}\text { Qualitative methods / } \\
\text { Quantitative methods }\end{array}$ \\
\hline 3 & Descriptive research & $\begin{array}{l}\text { To investigate the facts aimed at } \\
\text { describing the characteristics of the } \\
\text { system }\end{array}$ & Qualitative methods \\
\hline 4 & Casual research & To reveal cause and affect relations & Quantitative methods \\
\hline
\end{tabular}

The key ideas directing qualitative research are different from those in quantitative research. The suitability of methods and theories, opinions of the participants and their differences, thinking process of the researcher and the research and the diversified approaches and methods are the essential features of qualitative research. The qualitative research focuses on description and interpretation and 
might lead to the development of new concepts or theory, or to an evaluation of an organizational process.

Qualitative research methods might be employed for exploratory studies for formulating and designing the research problem and hypotheses, as inputs for designing the structured questionnaires, as the primary sources of research inquiry for a clinical analysis, where the task is to uncover the reasons for certain occurrences and with segments like children. The use of qualitative research methods generates an in-depth knowledge of the individuals' beliefs, attitudes, and behaviour. The qualitative research methods also provide the ability to understand the changing nature of the industry and key issues and provide a more adjustable and unstructured approach [2].

Table 2 : Type of Qualitative Research Methods

\begin{tabular}{|c|c|c|c|}
\hline S. No. & $\begin{array}{l}\text { Qualitative Research } \\
\text { Methods }\end{array}$ & Objective & Procedure \\
\hline 1 & Observation Method & $\begin{array}{l}\text { Observation of the system } \\
\text { and its environment }\end{array}$ & $\begin{array}{ll}\begin{array}{l}\text { Data collection } \\
\text { observation }\end{array} & \text { via }\end{array}$ \\
\hline 2 & Content Analysis & $\begin{array}{lll}\text { Investigating } & \text { a } & \text { report } \\
\text { systematically } & & \\
\end{array}$ & Structured and systematic \\
\hline 3 & Focus Group Method & $\begin{array}{l}\text { Collection of information } \\
\text { from group }\end{array}$ & $\begin{array}{l}\text { Analysing the information } \\
\text { from focus groups }\end{array}$ \\
\hline 4 & $\begin{array}{ll}\text { Personal Interview } \\
\text { method }\end{array}$ & $\begin{array}{l}\text { Opinion/experience } \\
\text { Collection }\end{array}$ & $\begin{array}{l}\text { May be unstructured, semi- } \\
\text { structured and structured }\end{array}$ \\
\hline 5 & Projective techniques & $\begin{array}{l}\text { Idea of projecting one-self or } \\
\text { feelings on ambiguous } \\
\text { objects }\end{array}$ & Indirect questioning \\
\hline 6 & Socio-metric analysis & \begin{tabular}{lrr}
$\begin{array}{l}\text { Analysing } \\
\text { obtained } \\
\text { groups }\end{array}$ & \multicolumn{2}{r}{ from } \\
\end{tabular} & $\begin{array}{l}\text { Involves measuring the } \\
\text { choice, communication and } \\
\text { interpersonal relations of } \\
\text { people in different groups. }\end{array}$ \\
\hline 7 & Research Case Analysis & $\begin{array}{l}\text { Analysing certain issues of a } \\
\text { company or an industry }\end{array}$ & $\begin{array}{l}\text { Use suitable analysing } \\
\text { framework }\end{array}$ \\
\hline 8 & $\begin{array}{l}\text { Patent Analysis } \\
\text { (Proposed in this paper) }\end{array}$ & $\begin{array}{l}\text { Analysing a patent granted } \\
\text { on a new product or new } \\
\text { process or new system }\end{array}$ & $\begin{array}{l}\text { Use of suitable framework to } \\
\text { analyse technology/ process }\end{array}$ \\
\hline
\end{tabular}

Irrespective of the type of research /method of inquiry, it must adhere to certain established criteria to be called as business research / technology research. For a research to be of value and to authenticate or contribute to the body of knowledge, it must possess the following features: (1) Clearly defines purpose, (2) System of examining the research problem, (3) developing hypotheses, and (4) finding an optimum solution based on hypothesis. Sometimes new interpretation of the solution through systematic analysis also considered as qualitative research.

There are two universally practiced and easily comprehensible classification on the type of research. They are exploratory research and conclusive research. Explorative research is based upon the objectives of solving the problem of study and the conclusive research is based on the purposes of the study. Both Case Analysis research method [3-6] and Patent analysis research method proposed in this paper are different from explorative research and conclusive research in such a way that they have both objectives of study and purpose of the study. In this paper, we have proposed and outlined a new method of doing research especially for beginners in applied sciences including engineering, business management, agricultural sciences, pharmaceutical sciences, medical sciences, paramedical sciences etc where a huge number of patents are filed world over every year (table 3). Patents are considered as big data because during last 10 years on an average 25 lakhs patents are filed per year from all over the world and out of them around $70 \%$ patents are accepted by the review committees. These patents developed and filed according to a specific format with a major information resource which describes new technologies and new concepts. The patent literature is different from any other 
information source as the information disclosed in this literature is not published elsewhere. Patents provide valuable information on current technology and their usage on building products or processes and such information is useful for researchers, R \& D managers, technologists, and forecasters to enable them to predict as well as formulate corporate policies and strategies. The major advantage of patent literature is to indicate gaps in the area of research where inventor, as well as the analyser, can put efforts to innovate new ideas and interpret them in the new and relevant way.

Table 3 : World patent application scenario during last 10 years [7]

\begin{tabular}{|l|l|l|}
\hline S. No. & Year & Number of Patents \\
\hline 1 & 2017 & - \\
\hline 2 & 2016 & $31,27,900$ \\
\hline 3 & 2015 & $28,87,300$ \\
\hline 4 & 2014 & $26,80,800$ \\
\hline 5 & 2013 & $25,64,900$ \\
\hline 6 & 2012 & $23,56,600$ \\
\hline 7 & 2011 & $21,58,100$ \\
\hline 8 & 2010 & $19,97,200$ \\
\hline 9 & 2009 & $18,55,500$ \\
\hline 10 & 2008 & $03,13,700$ \\
\hline 11 & 2007 & $02,73,000$ \\
\hline 12 & 2006 & $17,91,000$ \\
\hline 13 & 2005 & $17,02,800$ \\
\hline 14 & 2004 & $15,74,200$ \\
\hline 15 & 2003 & $14,84,000$ \\
\hline 16 & 2002 & $14,44,000$ \\
\hline 17 & 2001 & $14,57,000$ \\
\hline
\end{tabular}

Table 4 contains the country wise patent application data from the year 2011 to 2016. It is seen that China is maintained the first position which is followed by the United States of America and then Japan in patent application ranking. These patents carry a good amount of information on possible new products or processes in different subject areas. This untapped innovation mine can be used for analysis based on a systematically developed procedure to understand and to develop further new ideas or improving the features of existing ideas.

Table 4 : World patent application scenario during last 5 years - Top 7 Countries [7]

\begin{tabular}{|l|l|l|l|l|l|l|l|}
\hline $\begin{array}{l}\text { S. } \\
\text { No. }\end{array}$ & Country & $\mathbf{2 0 1 1}$ & $\mathbf{2 0 1 2}$ & $\mathbf{2 0 1 3}$ & $\mathbf{2 0 1 4}$ & $\mathbf{2 0 1 5}$ & $\mathbf{2 0 1 6}$ \\
\hline 1 & China & $5,26,412$ & $6,52,777$ & $8,25,136$ & $9,28,177$ & $11,01,864$ & $13,38,503$ \\
\hline 2 & USA & $5,03,582$ & $5,42,815$ & $5,71,612$ & $5,78,802$ & $05,89,410$ & $06,05,571$ \\
\hline 3 & Japan & $3,42,610$ & $3,42,796$ & $3,28,436$ & $3,25,989$ & $03,18,721$ & $03,18,381$ \\
\hline 4 & $\begin{array}{l}\text { Republic of } \\
\text { Korea }\end{array}$ & $1,78,924$ & $1,88,915$ & $2,04,589$ & $2,10,292$ & $2,13,694$ & $2,08,830$ \\
\hline 5 & $\begin{array}{l}\text { Russian } \\
\text { Federation }\end{array}$ & 41,414 & 44,211 & 44,914 & 40,308 & 45,517 & 41,587 \\
\hline 6 & Germany & 59,444 & 61,340 & 63,167 & 65,965 & 66,893 & 67,899 \\
\hline 7 & India & 42,291 & 43,955 & 43,031 & 42,854 & 45,658 & 45,057 \\
\hline
\end{tabular}

\section{PATENT ANALYSIS AS A QUALITATIVE RESEARCH METHOD :}

A patent is a right granted to the inventor that prevents others from making, using, selling, importing the invention without his/her permission. A patentable invention can be a product or process that gives a new technical solution to a problem [x]. Patent is a 
- (1) A new Invention of Product/Process.

- (2) Improvements in System/Item.

- (4) New/improved process

- (5) New model/idea

A patent is a legal document granted by the government giving an inventor the exclusive right to make, use, and sell an invention for a specified number of years (but not permission). Patents are also available for significant improvements on previously invented items.

To qualify for a patent, the invention must meet three basic tests :

- First, it must be novel, meaning that the invention did not previously exist.

- Second, the invention must be non-obvious, which means that the invention must be a significant improvement to existing technology/process. Simple changes to previously known devices do not comprise a patentable invention.

- Finally, the proposed invention must be useful. Legal experts commonly interpret this to mean that no patent will be granted for inventions that can only be used for an illegal or immoral purpose.

Details of Invention to be included in the Patent Application

- Title of the Invention

- Abstract of Invention

- Specification of Invention

- Description of Invention

- Claims of Invention

- Citation of other Patents

Procedure of Applying for Patent

- Patentable resource

- Inventor :

- Patentee (one or team)/Assignee Details

- Patent filing with date

- Patent Fee

Patent Forms

- Form 1 : APPLICATION FOR GRANT OF PATENT

- Form 2 : PROVISIONAL/COMPLETE SPECIFICATION

- Form 3 : Declaration \& Undertaking

- Form 5 : DECLARATION AS TO INVENTORSHIP

Fee for Patent [9]

- Rs. 1750 / patent

- bank draft or cheque payable to the Controller of Patents and drawn on a scheduled bank at the place where the appropriate office is situated.

- If the draft or cheque is sent by post, the fee shall be deemed to have been paid on the date on which the draft or cheque would have reached the Controller in the ordinary course of mail.

Patent Filing Procedure

(1) Patent Application - Form No. 1

With details of Inventor, Title of Invention, Declaration etc.

(2) Provisional specification / Complete specification - Form No. 2

(3) Statement and undertaking on Form No. 3

(4) Declaration of inventorship on Form No. 5

(5) Fee in the form of Bank DD. (Rs. 1,750/patent for individuals)

World Intellectual Property Organization (WIPO) defined patent as an exclusive right granted for an invention may be a product or a process which gives a new way of preparing and providing a solution to a problem. It protects novel inventions and manufacturing processes for the duration of 20 years [7]. It is a territorial protection and can be sold or licensed. Patent protection implies that inventions cannot be commercially made, used, distributed or sold without the patent owner's consent. A patent owner has rights to decide who may or may not use the protected invention for the period in which the invention is protected. Patent provides an incentive to the creator for his invention. Filing of the patent application to patent office is mandatory. A patent is granted by a national patent office or 
regional patent office on the basis of the application. Every country has its own patent office and its own patent law for the protection of innovative ideas. Rights given by the patents are monopoly rights which prevent others from making, using or selling the creator's invention for a specified period of time. Patents are issued for inventions which are solutions to specific problems in the field of technology. Invention may be related to a product or a process. In order to get a patent for an invention, the invention has to be patentable (Novel, nonobvious, inventive step, utility etc) and application must be filed in the patent office. In summary, Patents reward disclosure rather than secrecy. Patent document is published as an application and later granted by the patent office after review as a patent. Patents are granted for the inventions related to process, products, apparatus, and industrial applications [7].

\section{Contents of Patent Application}

- Application for grant of patent in Form-1.

- Applicant has to obtain a proof of right to file the application from the inventor. The Proof of Right is either an endorsement at the end of the Application Form-1 or a separate assignment.

- Provisional / complete specification in Form-2.

- Statement and undertaking under Section 8 in Form-3, if applicable.

- An applicant must file Form 3 either along with the application or within 6 months from the date of application.

\section{What is not patentable?}

- Some inventions cannot be patented. Under the law of the European Patent Convention (EPC), the list of non-patentable subject-matter includes methods of medical treatment or diagnosis, and new plant or animal varieties.

- Further information on such fields can be obtained from a patent attorney. Nor may patents be granted for inventions whose exploitation would be contrary to public order or morality.

- The following are not regarded as inventions: discoveries; scientific theories and mathematical methods; aesthetic creations, such as works of art or literature; schemes, rules, and methods for performing mental acts, playing games or doing business; presentations of information; computer software.

Under the Indian law, the following are non-patentable :

- An invention which claims anything obviously contrary to well established natural laws. An invention of the primary or intended use of which would be contrary to law or morality or injurious to public health. The mere discovery of a scientific principle or the formulation of an abstract theory.

- The mere discovery of any new property or new use for a known material or of a known process, machine or apparatus unless such things results in a new product or adds at least one new reactant.

- A material obtained by a just admixture resulting only in the aggregation of the properties of the its components or a process for producing such material.

- The re-arrangement or duplication of existing devices each functioning independently of one another in a known way.

- A method or a process of testing applicable during the process of manufacture for rendering the machine, apparatus or other equipment more efficient or for the improvement or restoration of the existing machine, apparatus or other equipment or for the improvement or control of manufacture.

- A method of agriculture or horticulture.

- Any process for the medicinal, surgical, curative, prophylactic or other treatment of human being or any process for a similar treatment of animals or plants to render them free of disease or to increase their economic value or that of their products.

- No Patent shall be granted in respect of an invention relating to Atomic energy.

- Claiming substances intended for use, or capable of being used, as food or as medicine or drug Relating to substance prepared or produced by chemical processes (including Alloys, optical glass, semiconductor and inter-metallic compounds), no patent shall be granted in respect of claims for the substances themselves but claims for the methods or processes of manufacture shall be patentable.

- The criteria under the US laws are also quite similar as above. Books, movies, and works of art cannot be patented, but protection is available for such items under the law of copyright. 


\section{ANALYSING A PATENT :}

Analysing an issue is nothing but the detailed examination of the structure, elements, and various affecting factors of that issue. The analysis includes the process of breaking an issue into smaller parts called elements or components in order to understand it in a better way. The analysis also helps to uncover and understand the cause-effect relationships and hence provides a basis for problem solving and decision making. The definition of analysis changes from subject to subject and in general it is nothing but the detailed study of the given issue. If the analysis of an issue in any subject leads to better or new interpretation of the concepts related to that issue, then it is also called research. Many analysis frameworks are used in business management to analyse a system, concept, idea, strategy or models which include SWOT/SWOC analysis [10,11, 12, 13, 14], ABCD analysis [15, 16, 17], PESTEL analysis [18, 19, 20], Competitive forces analysis [21] etc. These analysis frameworks use some constructs to examine the elements or components and affecting factors for detailed analysis. Thus, any scholarly researcher can either create new knowledge or interpret any issue or concept in a new way through suitable analysis technique to qualify it as research. Patent is a new knowledge on an invention may be a product or process so that if analysed properly, may give rise to a new interpretation. As mentioned before, there are plenty of patents filed during many years in different subjects so that there are abundant opportunities for the scholarly researchers to analyse and interpret them so that it may even lead to new knowledge.

\subsection{Why Patent Analysis:}

A systematic Patent analysis gives us an insight into the filed patent/ accepted patent in a given subject and field. Patent analysis can be divided into two types - Individual patent analysis and Group patent analysis. In individual patent analysis, a patent filed on a product, or process, or on a technology filed by an individual or group of people, or by a company is analysed as per analysis framework. In group patent analysis, a group of related patents in an industry or of a same technology are analysed or compared as per the procedure. There are various analysis frameworks can be used to analyse a patent like Patent opportunity analysis, Patent performance analysis, Patent Innovation analysis, Patent technology analysis, Patent value analysis etc along with analysis of patent (product / process) features and claims. Systematic patent analysis is a new field untapped but provides new knowledge and new interpretations and hence is assumed as a gold mine for scholarly researchers. Patent analysis can be carried out for following reasons:

\section{(a) Forecasting emerging technologies:}

Detailed patent analysis with the description and claims based on a given technology may the researcher to forecast emerging technologies in the society including the technology used in the patent [22].

(b) Mapping inventive activity and technological change:

Detailed patent analysis with the description and claims allows an analyser to map inventive activities and technological changes in a given industry [23].

(c) Evaluating the risk of patent infringement:

Detailed analysis of a patent on its innovativeness in attracting customers through its future business value may be used to evaluate the risk of infringement [24].

(d) Technology trends identification:

Detailed patent analysis may uncover the trends in changes in technology during near future. Such identification of technology trend gives an idea to business firms on decision of investments in a given technology [25].

(e) Estimation of technological impact:

The technological impact in new product/process development and its effectiveness in deciding the future business is one of the reasons of patent analysis [26].

(f) Identifying technological topics and institution-topic distribution probability :

Based on a company's patent analysis one can determine the probability of technological topics and institution-topic distribution [27].

(g) Monitoring technology trends : 
Patent analysis in a given field and given industry monitors the technology trends in that industry and allows new researcher's to look into new inventions in the same or related concepts for further improvement [28].

(h) Technology valuation through Patent Analysis :

Quantitative Patent analysis also allows the valuation of the technology used to develop the product or process [29].

(i) To know state-of-the-art technology development in a given subject :

By analysing a given patent in terms of its technology, it is possible to know state-of-the-art technology development in a given subject [30].

(j) Mapping technological innovations :

By means of analysing several patents in a given industry, it is possible to map technological innovations [31].

(k) Business planning based on technological capabilities :

Patent analysis also allows a researcher to know its business value and hence it is possible to plan a business based on its technological capabilities [32].

(l) Analysing the functional dynamics of technological innovation systems :

It is proposed that the patent analysis also allows to Analyse the functional dynamics of technological innovation systems [33].

(m) Strategic planning for technology development with patent analysis :

Organizations can plan their strategy for new product for improving and expanding the market or new processes for improving the productivity or wastage through new technology development with patent analysis [34].

(n) Monitoring trends of technological changes :

Patent analysis also supports to monitor technological changes [35].

(o) Patents as indicators of corporate technological strength :

Patents analysis of patents submitted by corporates gives indications of their technological strength [36].

(p) To study the technology life cycle development :

Patents analysis also can be used to study the technological life cycle development and to know the used technologies current stage in its lifecycle [37].

(q) Organizational behaviour in the $R \& D$ process :

Patents analysis also indicates the organizational behaviour and their interest in motivating the employees in R \& D process and developing and filing patents [38].

(r) Detecting signals of new technological opportunities :

By analysing the patents filed by many organizations in a given industry, one can detect the signals of new technological opportunities [39].

(s) For promoting technology transfer in multi-technology industries :

Patent analysis also provides an opportunity to promote technology transfer in multi-technology industries [40].

(t) Prediction of emerging technologies :

Many patent analysis in a given industry supports the prediction of emerging technologies [41].

(u) Patent-based inventor profiles as a basis for human resource decisions :

Patent analysis also helps to identify inventor profile as a basis for human resource decisions in an organization which has focus on investing on R \& D [42].

(v) Assessing the industrial opportunity :

Group patent analysis in a given industry helps in assessing the industrial opportunity for expansion, collaboration, and expansion [43].

Apart from the above reasons, there may be many additional interests shown below for a researcher in patent analysis.

- Academic Interest - To study the contents and new claims of the patents by higher education students and researcher of relevant field

- Technological Perception - To study the technological ability to solve real world problems and to find optimum solutions for them. 
- Predicting the future - Decision makers in organizations can foresee the future based on analysing group of patents in a given industry sector.

- Researching for new Ideas - Patent analysis will give rise to new ideas of solving problems in same area and related area. It may also lead to think out of the box to find new solutions to existing problems.

- New/Improved Invention \& Patent - Based on analysing many patents by students and researchers, new invention may get birth leading to filing of new patents.

\subsection{Historical Development on Patent Analysis :}

Patents originated in the 15th century when Florence of Italy issued patent protection to a gear used in barge hoists developed as new technology by its citizen Filippo Brunelleschi. Since then, many governments worldwide have started to issue patents to encourage technological inventions by promoting innovation.

\subsection{Types of Patents}

There are three types of patents as described by the USPTO:

(1) Utility: This type of patents is granted for the invention or discovery of a new product, process, machine, article of manufacture, or composition of matter; or for the improvement of existing systems.

(2) Design: This type of patents is granted for a new, original, or ornamental design for a manufactured article.

(3) Plant: This type of patents is granted for the invention or discovery and reproduction of a new type of plant.

\subsection{Identifying a Patent for Analysis :}

Depending upon the interest of the researcher, he/she can choose a patent from the topic relevant to his/her specialization area. The choice of the patent may be of industry-based, pure science-based, applied science or engineering-based, patent filed by a specific company, patent filed by a specific business group, patent filed by individuals, or patent filed on a specific solution of a problem.

\subsection{Patent Analysis Procedure :}

(1) Identifying a Patent :

- Search a Patent in a given Industry/ Application/ Technology/ Subject using Google Patent www.patents.google.com/as per the procedure stated in section 3.4.

(2) Study the summary of the Patent :

- Using Abstract of the patent given in patent form.

(3) Classification of the patent :

- To know the category of the patent.

(4) Description on Patent :

- Available in the Patent under analysis.

(5) Description /Comments on Drawings of a Patent :

- Available in the patent from Google patent form.

(6) Detailed Description on the Invention :

- Available in the patent from Google patent form.

(7) Claims of the Invention :

- Available in the patent from Google patent form.

(8) Number of Citations in the Patent:

- Available in the patent from Google patent form.

(9) Number of Citations for the Patent:

- Available in the patent from Google patent form.

(10) List of Similar Inventions:

- Available in the patent from Google patent form.

(11) Legal Issues Related to Inventions (Optional) :

- Available in the patent from Google patent form.

\section{PATENT ANALYSIS FRAMEWORKS :}

It is possible to develop different types of patent analysis frameworks based on the analysis objectives and theme. Some of the possible frameworks are described below : 
4.1 Patent opportunity analysis : This can be systematic analysis deals with identifying the opportunities of the patent based on the technology used, solutions possible, claims described and application of the patented product/process in designing new things to solve current and future problems.

4.2 Patent performance analysis :This is a systematic analysis of the possible performance of the invented /proposed product/ process in order to fulfil the promises based on the claims.

4.3 Patent Innovation analysis :This can be an analysis of possible innovations in related fields based on the granted patent and its technology.

4.4 Patent technology analysis :The technology used in the patent to develop stated product/ process or new discovery of a material etc. The organizational, industrial and environmental effects due to such invention and technology in supporting or affecting the future business etc.

4.5 Patent value analysis :This model of analysis consists of estimating the business value of the patent from the frame of reference of different stakeholders. In this analysis, the various attributes of the patent and their effect on creating both tangible value and intangible value are the features of study.

4.6 Patent (product / process) features and claims :The various features of patented product or process are analysed in order to improve the performance from all stakeholders point of view and by studying the claims from the patented application.

4.7 Qualitative Analysis of the patent using ABCDEF Listing :In this method, the advantages, benefits, constraints, disadvantages, effectiveness, and future financial value of the patent in the frame of reference of various stakeholders has to be listed separately [44-50].

4.8. Factors and Elemental analysis as Quantitative analysis of the patent using ABCDEF framework :

This analysis framework is the extension of recently invented ABCD framework developed by Aithal P. S. et al, used for analysing systems, concepts, ideas, models, strategies etc. [15-16, 51-60]. This framework allows the researchers to determine various affecting factors of a patent under four constructs of advantages (A), benefits (B), constraints (C), and Disadvantages (D), effectiveness (E), and future financial value (F) for various determinant issues using some common attributes. The framework also allows us to do elementary analysis to identify various constituent elements under the same constructs advantages, benefits, constraints, disadvantages, effectiveness, and future financial value of the patent. This analysis framework is very effective and can be further improved by offering scores to each constituent element under those six constructs using focus group method.

\section{ABCDEF ANALYSIS OF THE PATENT :}

A systematic procedure of analysing a patent using ABCDEF framework consists of following steps :

(1) Importance of the Invention :

Patent analysis should contain a summary of the importance of the invention of the patented product, process, material or system. The importance may be of technology used, the complexity of the product, its usage in society or systems, cost of development, maintenance etc.

(2) Description of the Invention :

This stage consists of the highlight on various features of the invention along with a summary of the description given in the patent application.

(3) Design :

The design part of the invention may contain description about drawings, the technology used, analysis on easiness of production, Cost, Reliability, Resource availability, and Durability of the patented item,

(4) New Innovations \& Value addition in the Patent :

In this section, the analyser discusses on possible further improvement and how this patent is going to add value to the industry or users.

(5) ABCDEF Analysis of the Patent :This step is the core part of the analysis and in this section, the advantages, benefits, constraints, disadvantages, effectiveness, and future financial value when realizing the patented item in practice has to be listed from the various stakeholder point of view in the qualitative listing. On other hand, by identifying the affecting factors and critical constituent elements using statistical weightage, as the constructs - advantages, benefits, constraints, 
disadvantages, effectiveness, and future financial value, the quantitative analysis can be developed [15-16]. The development of detailed procedure on ABCDEF framework for patent analysis is under progress and will be published soon in another article.

(6) Business Opportunities \&Challenges :

The patent under consideration can be also analysed by studying the business opportunities and challenges in detail. SWOC analysis can be used at this stage to know strength of the invention, weakness of the invention, opportunities for the invention and challenges for the invention to realize it in practice.

\section{USE \& APPLICATIONS OF PATENT ANALYSIS :}

Patent analysis not only creates new knowledge and new interpretation but also educates the researchers to create and own intellectual properties. Based on analysis of existing patents by researchers of students of higher education, they may get new ideas to develop innovative products and optimal processes, may lead to the birth of new entrepreneurs. Business organizations may create new sections of patent analysis along with an existing focus on creating patents to use them in their technology development programmes, of course, by offering royalty to the inventor [61-65].

(1) Awareness Creation on Patents : Patent analysis by scholarly researchers creates awareness about patents, their design, structure, and format, the claims included in the patent and the technology used. While analysing patents, the researcher also studies the other patents related to the patents under analysis through observing the many citation patents which are related, relevant to this patent. Patent analysis creates awareness on writing a patent on their innovations so that researchers get motivated to think and develop new patents in future days.

(2) Academic Curriculum for Innovative thinking : Introducing patent analysis in higher education institutions as a compulsory value added subject in the third and final year of the course of study will create awareness among students about new inventions using innovative technologies to find better solutions to existing problems. Such awareness may lead to new inventions further and hence provides an opportunity for the students to think innovatively and publish scholarly papers.

(3) New Idea Generation : Patent analysis of existing ideas may lead to new ideas when it is done systematically. Such new ideas may give rise to further new patents through new inventions. Hence patent analysis may produce the cumulative effect of increased patent filing by students and researchers.

(4) Industries \& Organizations for new Inventions : Patent analysis supported by organizations and industries will lead to better contribution by human resources to new knowledge creation through new inventions based on better exposure on structure and process of patenting.

\section{CONCLUSION :}

Many methods and methodologies are used in scholarly research under two general headings of qualitative research and quantitative research. Qualitative research uses all the relevant methods and methodologies without using statistical analysis techniques to create new knowledge and to interpret existing knowledge in a new way using various analysis frameworks. Quantitative research, on other hand, uses statistical techniques to find relationships between various variables in a problem to create new knowledge. Research case studies and newly proposed patent analysis are qualitative techniques but can be promoted as quantitative techniques based on what kind of analysing frameworks used. This new research method of patent analysis is expected to make use of huge untapped information sources of reviewed patents on different technologies used to produce a new product, process, material, or application to analyse them in a systematic way to create new knowledge or new interpretations. The present proposal hinted at available new research opportunities for researchers both at entry level and advanced level to identify and analyse patents available in all subject areas and discussed the possibilities of using various analysing frameworks. The possible use and applications of patent analysis are also highlighted. This new avenue of using patent analysis as a research method can be effectively used by students of engineering, medical, paramedical, business management and other applied studies students both at bachelor and master's degree level to rename their course as research focussed courses. 


\section{REFERENCES :}

[1] Lewis, S. (2015). Qualitative inquiry and research design: Choosing among five approaches. Health promotion practice, 16(4), 473-475.

[2] Hoepfl, M. C. (1997). Choosing qualitative research: A primer for technology education researchers. Journal of technology education, 9(1), 47-63.

[3] Baxter, P., \& Jack, S. (2008). Qualitative case study methodology: Study design and implementation for novice researchers. The qualitative report, 13(4), 544-559.

[4] Aithal, P. S. (2017). Industry Analysis - The First Step in Business Management Scholarly Research. International Journal of Case Studies in Business, IT and Education (IJCSBE), 2(1), 1-13. DOI: http://dx.doi.org/10.5281/zenodo.810347.

[5] Aithal, P. S., (2017). Company Analysis - The Beginning Step for Scholarly Research. International Journal of Case Studies in Business, IT and Education (IJCSBE), 1(1), 1-18. DOI: http://dx.doi.org/10.5281/zenodo.573769.

[6] Aithal, P. S. (2017). An Effective Method of Developing Business Case Studies Based on Company Analysis. International Journal of Engineering Research and Modern Education (IJERME), 2(1), 16-27. DOI: http://dx.doi.org/10.5281/ZENODO.400579.

[7] WIPO statistics database, https://www3.wipo.int/ipstats/index.htm?tab=patent retrieved on 20/08/2018.

[8] http://www.ipindia.nic.in/ referred on 20/08/2018.

[9] http://www.ipindia.nic.in/writereaddata/Portal/IPOFormUpload/1_11_1/Fees.pdf referred on 20/08/2018.

[10] Revathi, R., Madhushree, L. M. \& Aithal, P. S. (2018). Business Strategy of Top Indian Company: L\&T InfoTech. International Journal of Case Studies in Business, IT and Education (IJCSBE), 2(1), 64-89. DOI: http://dx.doi.org/10.5281/zenodo.1302770.

[11] Aithal, P. S. and Suresh Kumar, P. M. (2015). Applying SWOC Analysis to an Institution of Higher Education. International Journal of Management, IT and Engineering (IJMIE), 5(7), 231-247. DOI: http://doi.org/10.5281/zenodo.163425.

[12] Madhushree, L. M., Revathi, R., Anil Kumar, Aithal, P.S., (2018). Business Strategies of Top Indian IT Company: Mindtree. International Journal of Case Studies in Business IT and Education (IJCSBE), 2(1), 22-36. DOI: http://dx.doi.org/10.5281/zenedo.1249871.

[13] Jithin Raj, K. \& Krishna Prasad, K. (2018). A Critical Study on Business Strategies of 3i Infotech Ltd. International Journal of Case Studies in Business, IT and Education (IJCSBE), 2(1), 13-21. DOI: http://dx.doi.org/10.5281/zenodo.1247319.

[14] Sneha, M. S. \& Krishna Prasad, K. (2018). Analysis of Business Strategies of Salesforce.com Inc. International Journal of Case Studies in Business, IT and Education (IJCSBE), 2(1), 37-44. DOI: http://dx.doi.org/10.5281/zenodo.1252028.

[15] Aithal, P. S., V.T. Shailashree, P. M. Suresh Kumar, (2015). A New ABCD Technique to Analyze Business Models \& Concepts. International Journal of Management, IT and Engineering (IJMIE), 5(4), 409 - 423. DOI : http://doi.org/10.5281/zenodo.61652.

[16] Aithal, P. S., (2016). Study on ABCD Analysis Technique for Business Models, Business Strategies, Operating Concepts \& Business Systems. International Journal in Management and Social Science, 4(1), 98-115. DOI: http://doi.org/10.5281/zenodo.161137.

[17] Aithal, P. S., (2017). ABCD Analysis as Research Methodology in Company Case Studies. International Journal of Management, Technology, and Social Sciences (IJMTS), 2(2), 40-54. DOI: http://dx.doi.org/10.5281/zenodo.891621. 
[18] Gupta, A. (2013). Environment \& PEST analysis: an approach to external business environment. International Journal of Modern Social Sciences, 2(1), 34-43.

[19] Aithal P. S., (2017). Impact of Domestic, Foreign, and Global Environments on International Business Decisions of Multinational Firms: A Systematic Study. International Journal of Management, Technology, and Social Sciences (IJMTS), 2(2), 57-73. DOI: http://dx.doi.org/10.5281/zenodo.1067103.

[20] Aithal P. S. (2017). A critical study on Various Frameworks used to analyze International Business and its Environment. International Journal of Applied Engineering and Management Letters (IJAEML), 1(2), 74-98. DOI:http://dx.doi.org/10.5281/zenodo.1053578.

[21] Porter, M. E. (1985). Competitive Advantage: Creating and Sustaining Superior Performance. New York: The Free Press.

[22] Daim, T. U., Rueda, G., Martin, H., \&Gerdsri, P. (2006). Forecasting emerging technologies: Use of bibliometrics and patent analysis. Technological Forecasting and Social Change, 73(8), 981-1012.

[23] Bhattacharya, S. (2004). Mapping inventive activity and technological change through patent analysis: A case study of India and China. Scientometrics, 61(3), 361-381.

[24]Bergmann, I., Butzke, D., Walter, L., Fuerste, J. P., Moehrle, M. G., \& Erdmann, V. A. (2008). Evaluating the risk of patent infringement by means of semantic patent analysis: the case of DNA chips. $R$ \& $d$ Management, 38(5), 550-562.

[25]Choi, S., Yoon, J., Kim, K., Lee, J. Y., \& Kim, C. H. (2011). SAO network analysis of patents for technology trends identification: a case study of polymer electrolyte membrane technology in proton exchange membrane fuel cells. Scientometrics, 88(3), 863.

[26]Choi, C., Kim, S., \& Park, Y. (2007). A patent-based cross impact analysis for quantitative estimation of technological impact: The case of information and communication technology. Technological Forecasting and Social Change, 74(8), 1296-1314.

[27]Wang, B., Liu, S., Ding, K., Liu, Z., \& Xu, J. (2014). Identifying technological topics and institution-topic distribution probability for patent competitive intelligence analysis: a case study in LTE technology. Scientometrics, 101(1), 685-704.

[28]Bhattacharya, S., \& Khan, M. D. T. R. (2001). Monitoring technology trends through patent analysis: A case study of thin film. Research evaluation, 10(1), 33-45.

[29]Jun, S., Park, S., \& Jang, D. (2015). A technology valuation model using quantitative patent analysis: a case study of technology transfer in big data marketing. Emerging Markets finance and trade, 51(5), 963-974.

[30]Abbas, A., Zhang, L., \& Khan, S. U. (2014). A literature review on the state-of-the-art in patent analysis. World Patent Information, 37, 3-13.

[31]Wong, C. Y., \& Yap, X. S. (2011). Mapping technological innovations through patent analysis: a case study of foreign multinationals and indigenous firms in China. Scientometrics, 91(3), 773787.

[32]Lee, S., Yoon, B., Lee, C., \& Park, J. (2009). Business planning based on technological capabilities: Patent analysis for technology-driven road mapping. Technological Forecasting and Social Change, 76(6), 769-786.

[33]Bergek, A., Jacobsson, S., Carlsson, B., Lindmark, S., \&Rickne, A. (2008). Analyzing the functional dynamics of technological innovation systems: A scheme of analysis. Research policy, 37(3), 407-429.

[34]Liu, S. J., \&Shyu, J. (1997). Strategic planning for technology development with patent analysis. International Journal of Technology Management, 13(5-6), 661-680. 
[35]Lee, C., Jeon, J., \& Park, Y. (2011). Monitoring trends of technological changes based on the dynamic patent lattice: A modified formal concept analysis approach. Technological Forecasting and Social Change, 78(4), 690-702.

[36]Narin, F., Noma, E., \& Perry, R. (1987). Patents as indicators of corporate technological strength. Research policy, 16(2-4), 143-155.

[37]Haupt, R., Kloyer, M., \& Lange, M. (2007). Patent indicators for the technology life cycle development. Research Policy, 36(3), 387-398.

[38]Tsuji, Y. S. (2002). Organizational behavior in the R\&D process based on patent analysis: Strategic R\&D management in a Japanese electronics firm. Technovation, 22(7), 417-425.

[39]Yoon, J., \& Kim, K. (2012). Detecting signals of new technological opportunities using semantic patent analysis and outlier detection. Scientometrics, 90(2), 445-461.

[40]Park, Y., Lee, S., \& Lee, S. (2012). Patent analysis for promoting technology transfer in multitechnology industries: the Korean aerospace industry case. The journal of technology transfer, 37(3), 355-374.

[41]Érdi, P., Makovi, K., Somogyvári, Z., Strandburg, K., Tobochnik, J., Volf, P., \&Zalányi, L. (2013). Prediction of emerging technologies based on analysis of the US patent citation network. Scientometrics, 95(1), 225-242.

[42]Moehrle, M. G., Walter, L., Geritz, A., \& Müller, S. (2005). Patent-based inventor profiles as a basis for human resource decisions in research and development. R\&D Management, 35(5), 513524.

[43]Ogawa, T., \& Kajikawa, Y. (2015). Assessing the industrial opportunity of academic research with patent relatedness: A case study on polymer electrolyte fuel cells. Technological Forecasting and Social Change, 90, 469-475.

[44] Keerthan Raj, \& Aithal, P. S. (2018). Generating Wealth at the Base of the Pyramid - A Study using ABCD Analysis Technique. International Journal of Computational Research and Development (IJCRD), 3(1), 68-76. DOI :http://doi.org/10.5281/zenodo.1205586.

[45] Architha Aithal \& A. R. Shabaraya (2018). Users Perspectives on Online Pharmacy Model. International Journal of Health Sciences and Pharmacy (IJHSP), 2(1), 29-36. DOI: http://dx.doi.org/10.5281/zenodo.1292790.

[46] Narula, A.V., \& Aithal, P. S. (2018).Employability Skill traits Management Quotient [ESMQ] A Conceptual Model Proposal. International Journal of Applied Engineering and Management Letters (IJAEML), 2(1), 1-30. DOI: http://dx.doi.org/10.5281/zenodo.1156138.

[47] Aithal, P. S. (2017).ABCD Analysis of Recently Announced New Research Indices. International Journal of Management, Technology, and Social Sciences (IJMTS), 2(1), 65-76. DOI: http://doi.org/10.5281/ zenodo. 583644 .

[48] Aithal, P. S. (2017). Factor Analysis based on ABCD Framework on Recently Announced New Research Indices, International Journal of Management, Technology, and Social Sciences (IJMTS), 1(1), 82-94. DOI: http://dx.doi.org/1 0.5281/zenodo.584105.

[49] Aithal, Architha., Aithal, P. S. (2017). ABCD Analysis of Task Shifting-An optimum Alternative Solution to Professional Healthcare Personnel Shortage. International Journal of Health Sciences and Pharmacy (IJHSP), 1(2), 36-51. DOI: http://dx.doi.org/10.5281/zenodo.1038975.

[50] Varun Shenoy \& Aithal, P. S., (2017). Quantitative ABCD Analysis of IEDRA Model of Placement Determination. International Journal of Case Studies in Business, IT and Education (IJCSBE), 1(2), 103-113. DOI: http://dx.doi.org/10.5281/zenodo.1133691. 
[51] Aithal, P. S., Shailashree, V. T., \& Suresh Kumar, P. M. (2015). Application of ABCD Analysis Model for Black Ocean Strategy. International Journal of Applied Research (IJAR), 1(10), 331337. DOI: http://doi.org/ 10.5281/zenodo.163424.

[52] Aithal, P. S., Shailashree, V. T., \& Suresh Kumar P. M., (2016). ABCD analysis of Stage Model in Higher Education. International Journal of Management, IT and Engineering (IJMIE), 6(1), 11-24. DOI: http://doi.org/10.5 281/zenodo.154233.

[53] Aithal, P. S., Shailashree, V. T., \& Suresh Kumar, P. M. (2016). Analysis of NAAC Accreditation System using ABCD framework. International Journal of Management, IT and Engineering (IJMIE), 6(1), 30-44. DOI: http://doi.org/10. 5281/zenodo.154272.

[54] Aithal, P. S., Shailashree, V. T., \& Suresh Kumar, P. M. (2016). Application of ABCD Analysis Framework on Private University System in India. International Journal of Management Sciences and Business Research (IJMSBR), 5(4), 159-170. DOI :http://doi.org/10.5281/zenodo.161111.

[55] Aithal, P. S., Shailashree, V. T., \& Suresh Kumar, P. M. (2016). The Study of New National Institutional Ranking System using ABCD Framework, International Journal of Current Research and Modern Education (IJCRME), 1(1), 389-402. DOI :http://doi.org/10.5281/zenodo.161077.

[56] Aithal, S., \& Aithal, P. S. (2016). ABCD analysis of Dye doped Polymers for Photonic Applications, IRA-International Journal of Applied Sciences, 4 (3), 358-378. DOI: http://dx.doi.org/10.21013/jas.v4.n3.p1.

[57] Aithal, P. S., Shailashree, V. T. \& Suresh Kumar, P. M., (2016). Analysis of ABC Model of Annual Research Productivity using ABCD Framework. International Journal of Current Research and Modern Education (IJCRME), 1(1), 846-858. DOI :http://doi.org/10.5281/ zenodo.62022.

[58] Varun Shenoy, \& Aithal P. S., (2016). ABCD Analysis of On-line Campus Placement Model, IRA-International Journal of Management \& Social Sciences, 5(2), 227-244. DOI: http://dx.doi.org/10.21013/jmss .v5.n2.p3.

[59] Aithal, P. S., Shailashree V. T. \& Suresh Kumar P.M. (2016). Factors \& Elemental Analysis of Six Thinking Hats Technique using ABCD Framework. International Journal of Advanced Trends in Engineering and Technology (IJATET), 1(1), 85-95. DOI : http://doi.org/10.5281/zenodo.240259.

[60] Aithal, P. S. \& Suresh Kumar, P. M. (2016). CCE Approach through ABCD Analysis of 'Theory A' on Organizational Performance. International Journal of Current Research and Modern Education (IJCRME) 1(1), 169-185. DOI: http://dx.doi.org/10. 5281/zenodo.164704.

[61] Archibugi, D. (1992). Patenting as an indicator of technological innovation: a review. Science and public policy, 19(6), 357-368.

[62] OuYang, K., \& Weng, C. S. (2011). A new comprehensive patent analysis approach for new product design in mechanical engineering. Technological Forecasting and Social Change, 78(7), 1183-1199.

[63] Breitzman, A. F., \&Mogee, M. E. (2002). The many applications of patent analysis. Journal of Information Science, 28(3), 187-205.

[64] Dou, H., Leveillé, V., Manullang, S., \& JM Jr, D. (2005). Patent analysis for competitive technical intelligence and innovative thinking. Data science journal, 4, 209-236.

[65] Chang, S. B. (2012). Using patent analysis to establish technological position: Two different strategic approaches. Technological Forecasting and Social Change, 79(1), 3-15. 